\title{
Can We Prevent Cardio Vascular Morbidities and Mortalities?
}

\author{
Hamid Yahya Hussain* \\ Department of Health Affairs, Dubai Health Authority, UAE
}

Submission: November 23, 2017; Published: December 18, 2017

*Corresponding author: Hamid Yahya Hussain, Department of Health Affairs, Dubai Health Authority, UAE, Email: Hussainh569@gmail.com

\section{Opinion}

Cardivan-vascular dieses are group of disease which are totally preventable, it is concluded that almost $90 \%$ of CVD is avoidable. Improving risk factors is the key point in Prevention strategies, thus minimizing atherosclerosis process are significantly linked to improving risk factors by: healthy diet consumption, conducting exercises, eliminating tobacco smoke and educing alcohol intake. Lipids and high blood pressure management and control have great impact on CVD morbidities and mortalities. Applying effective strep throat with suitable antibiotics can contribute to decrease risk of rheumatic heart disease.

Cardiovascular diseases kept the main cause of mortality worldwide globally. It has been estimated that the mortality rate has been increased from 17.9 million deaths (32.1\%) in 2015, up from 12.3 million (25.8\%) in 1990 and have been increasing in much of the developing world, while rates have declined in most of the developed world since the 1970s. Recent figures about CVD revealed that Coronary artery disease and stroke account for $80 \%$ of CVD deaths in males and 75\% of CVD deaths in females. Older adults are still the most affected segment of population. Almost $11 \%$ of people between 20 and 40 in USA have CVD, while $37 \%$ between 40 and $60,71 \%$ of people between 60 and 80 , and $85 \%$ of people over 80 have CVD. The age of 80 years still considered as an average age of death from coronary artery disease in the developed on the contrary, the age 68 years in the developing world. More to that, the age of Disease onset is about seven to ten years earlier in men as compared to women.

Future cardiovascular event can still be predicted by Existing cardiovascular disease or a previous cardiovascular event, such as a heart attack or stroke. Age, sex, smoking, blood pressure, blood lipids and diabetes are sustained as predictors of future cardiovascular disease even in people who are not known to have cardiovascular disease. They are beside other measures recognized for composite risk scores to estimate an individual's future risk of cardiovascular disease. Diagnostic tests as well as biomarkers remain under evaluation for generating evidence to support their routine use. They include family history, coronary artery calcification score, high sensitivity C-reactive protein (hsCRP), ankle-brachial pressure index, lipoprotein subclasses and particle concentration, lipoprotein(a), apolipoproteins A-I and B, fibrinogen, white blood cell count, homocysteine, N-terminal pro B-type natriuretic peptide (NT-probing), and markers of kidney function. High blood phosphorus is also linked to an increased risk.

a. Cardiovascular disease mortalities and morbidities can be reduced by $35 \%$ through smoking cessation.

b. Dietary interventions are effective in reducing cardiovascular risk factors over a year.

c. Continuous physical activities At least 150 minutes (2 hours and 30 minutes) of moderate exercise per week reduces risk of subsequent cardiovascular events by $26 \%$.

d. Reducing Alcohol intake alcohol has a 25-30\% lower risk of cardiovascular disease.

e. Controlling hypertension, if elevated. Reducing $10 \mathrm{mmHg}$ reduction in blood pressure reduces risk by about $20 \%$.

f. About 31\% reductions in the mortality only by Decrease non-HDL cholesterol. Statin treatment reduces cardiovascular mortality by about $31 \%$.

g. Management of overweight and obesity can lead $46 \%$ reduction in cardiovascular risk.

h. Elevation stress is significantly associated with CVD mortalities.

i. Diet, Medication, CVD management, physical activities are all strongly associated with better CVD mortality outcomes as shown by research evidence.

Regarding MI, strategies using aspirin, atenolol, streptokinase or tissue plasminogen activator have been compared for qualityadjusted life-year (QALY) in regions of low and middle income. 
Globally CVD are the leading cause of death unless in Africa. About $30 \%$ of all global death was due to CVD in 2008. Death by CVD is much higher in low- and middle-income countries as over $80 \%$ of all global deaths caused by cardiovascular diseases occurred in those countries. It is also estimated that by 2030 , over 23 million people will die from cardiovascular diseases each year. Future wise about $60 \%$ of the world's cardiovascular disease burden will occur in the South Asian subcontinent although only accounting for $20 \%$ of the world's population. This may be secondary to a combination of genetic predisposition and environmental factors. Organizations such as the Indian Heart
Association are working with the World Heart Federation to raise awareness about this issue.

Research and evidence generation will have great impact on future mapping of CVD. The causes, prevention, and/or treatment of all forms of cardiovascular disease remain active fields of biomedical research, with hundreds of scientific studies being published on a weekly basis. Recent areas of research include the link between inflammation and atherosclerosis the potential for novel therapeutic interventions, and the genetics of coronary heart disease.

\begin{tabular}{l} 
Your next submission with Juniper Publishers \\
will reach you the below assets \\
- Quality Editorial service \\
- Swift Peer Review \\
- Reprints availability \\
- E-prints Service \\
- Manuscript Podcast for convenient understanding \\
- Global attainment for your research \\
- Manuscript accessibility in different formats \\
( Pdf, E-pub, Full Text, Audio) \\
- Unceasing customer service \\
Track the below URL for one-step submission \\
https://juniperpublishers.com/online-submission.php \\
\hline
\end{tabular}

